\title{
Mechanical Properties of Porcelain Containing Leucite Ion-exchanged with Rubidium
}

\author{
Hae-Hyoung LEE, Masayuki KON and Kenzo ASAOKA \\ Department of Dental Engineering, School of Dentistry, \\ The University of Tokushima, 3 Kuramoto-cho, \\ Tokushima, 770-8504 Japan
}

Received January 9, 1998/Accepted March 5, 1998

\begin{abstract}
The purpose of this study was to investigate the effectiveness of leucite crystals ion-exchanged with rubidium on the mechanical properties of glassy porcelain. For ion-exchange, a mixture of high-pure natural leucite $\left(\mathrm{KAlSi}_{2} \mathrm{O}_{6}\right)$ powder and $\mathrm{RbNO}_{3}$ were heat-treated at $450^{\circ} \mathrm{C}(\mathrm{RLa})$ or $650^{\circ} \mathrm{C}$ (RLb) for 1 hour. The density of leucite increased as a result of the rubidium ionexchange treatment. Polymorphic transformation temperatures of the ion-exchanged leucites were low compared with the unmodified leucite. Composite porcelains were prepared by blending each leucite ( $30 \mathrm{vol} \%)$ with "Component No.3" frit of Weinstein et al. patent. The flexural strength and fracture toughness of the glass-only and composite porcelains were measured by a three-point bending test and indentation technique. ANOVA and post hoc multiple comparisons test revealed that the flexural strength and fracture toughness of the composite porcelain containing $R L a$ were significantly higher $(p<.05$ and $p<.01$, respectively) than those of the other groups. The results suggested that the rubidium-ion-exchanged leucite (RLa) could be a better reinforcing agent for dental porcelain.
\end{abstract}

Key words: Dental porcelain, Rubidium leucite, Mechanical property

\section{INTRODUCTION}

Dental porcelains containing leucite crystals can be used in the fabrication of all types of fixed prostheses including metal-ceramic and all-ceramic restorations through various techniques ${ }^{1}$. Therefore, the leucite-containing porcelains continue to play a major role in aesthetic restorative dentistry. The leucite crystals are added to the dental porcelain as leucite-crystallized $\mathrm{frit}^{2)}$ or as pre-formed crystalline filler ${ }^{3)}$. High expansibility and suitable refractive index ${ }^{4)}$ of leucite against the glass matrix are the reasons why the leucite has been accepted as an ingredient of dental porcelains. However, the leucite-containing porcelains suffer from their relatively low mechanical properties, compared with those of some glass-ceramics or alumina $\left(\mathrm{Al}_{2} \mathrm{O}_{3}\right) /$ zirconia $\left(\mathrm{ZrO}_{2}\right)$-reinforced ceramics ${ }^{1,5)}$.

Mechanical failure of ceramics including dental porcelains is most likely caused by propagation of intrinsic or extrinsic cracks. Crystalline particles of high strength and elasticity can act as crack deflectors or stoppers in glassy porcelain, which results in substantial strengthening and toughening of the bulk object. The higher strength particles such as alumina and zirconia have been used for strengthening of dental ceramics ${ }^{1)}$. These particles added to glass, however, increase the opacity and 
firing temperature of the composite porcelain. Therefore, porcelains reinforced with some oxide crystals have limited use as restorative materials without the addition of a translucent veneering layer.

On the other hand, leucite-containing porcelains are strengthened by a mismatch of thermal expansion between the leucite particles and the glass matrix ${ }^{6)}$. However, cracks which propagate through glassy porcelain easily penetrate into the leucite particles, resulting in transgranular fracture ${ }^{7,8)}$, although some cracks deflect away from the leucite particles ${ }^{9)}$. One reason is that the mechanical properties of the crystalline leucite are much lower ${ }^{10)}$, compared with those of alumina and zirconia. This suggests the possibility that the mechanical properties of leucite porcelain could be improved by dispersing a toughened leucite filler. Then strong leucite particles can interrupt the crack propagation in glassy porcelain.

The structure of leucite $\left(\mathrm{KAlSi}_{2} \mathrm{O}_{6}\right)$ is based on a ( $\left.\mathrm{Si}, \mathrm{Al}\right)-\mathrm{O}$ framework similar to that of analcime $\left(\mathrm{NaAlSi}_{2} \mathrm{O}_{6} \cdot \mathrm{H}_{2} \mathrm{O}\right)$, and its unit cell has cavities which facilitate the ion-exchange reaction ${ }^{11}$. The rubidium ion is expected to enter the leucite lattice easily, and a larger monovalent cation replaces a smaller one in leucites ${ }^{12)}$. Thus, rubidium ions can be packed densely into leucite particles by an ion-exchange treatment, and this process may produce a toughening effect on the leucite particles.

The aim of this study was to test the hypothesis that the leucite particles ionexchanged with rubidium could be a better reinforcing agent of a glassy porcelain. High-purity natural leucite was used for the rubidium ion-exchange. The changes in thermal behaviors of various leucites with the ion-exchange treatment were investigated by a high-temperature x-ray diffraction method. The mechanical properties of the composite porcelains containing the rubidium-exchanged leucite were compared with those of the unmodified (untreated) leucite-containing porcelain.

\section{MATERIALS AND METHODS}

\section{Ion exchange of leucite}

In order to obtain rubidium-exchanged leucite particles, we used a natural crystalline leucite of high purity ( $\mathrm{K}\left[\mathrm{AlSi}_{2} \mathrm{O}_{6}\right]$ : Nichika, Kyoto, Japan) from Roccamonfina, Italy. The leucite crystals were pulverized in an alumina mortar and passed through a sieve of 325 mesh. Six grams of the powdered leucite was mixed with a solution of $4 \mathrm{~g}$ of rubidium nitrate $\left(\mathrm{RbNO}_{3}\right.$, Sigma, St. Louis, USA) in $10 \mathrm{~mL}$ of distilled water. For ion exchange of leucite, the mixture was heated at $450^{\circ} \mathrm{C}$ (RLa) or $650^{\circ} \mathrm{C}$ (RLb) for 1 $\mathrm{h}$ under an air atmosphere in a platinum crucible. After the heat-treatment, the leucite powder was removed from the furnace, and cooled in air. The treated leucite powders were cleaned ultrasonically in distilled water, three times for $5 \mathrm{~min}$. The leucite powder immersed in water was filtered through a filter paper following ultrasonification, and finally dried in an electric oven.

A high-temperature $\mathrm{x}$-ray diffraction method was also performed to analyze the rubidium-exchanged leucites, and to compare with the diffraction pattern of unmodified leucite (UL) reported in our previous paper ${ }^{6}$. The diffraction patterns of each 
Table 1 Specimens prepared in this study

\begin{tabular}{cccc}
\hline Group $(\mathrm{n}=9)$ & Matrix glass & Leucite $(30$ vol\%) & Firing temperature $\left({ }^{\circ} \mathrm{C}\right)$ \\
\hline $\mathrm{CNT}$ & & - & 870 \\
$\mathrm{UL}-\mathrm{C}$ & Component No.3 & $\mathrm{UL}$ & 1075 \\
$\mathrm{RLa}-\mathrm{C}$ & (CNT) & $\mathrm{RLa}$ & 1075 \\
$\mathrm{RLb}-\mathrm{C}$ & & $\mathrm{RLb}$ & 1075 \\
\hline
\end{tabular}

leucite over the $2 \theta$ range from $10^{\circ}$ to $50^{\circ}$ were obtained at temperatures of 50,400 , $450,500,550$, and $650^{\circ} \mathrm{C}$ using an x-ray diffractometer (XRD-6000, Shimadzu, Kyoto, Japan) with $\mathrm{CuK} \alpha$ radiation $(\lambda=1.5406 \dot{A})$. The diffraction intensities were measured by continuous scanning with a scan speed of $2.0^{\circ} / \mathrm{min}$ and a step width of $0.02^{\circ}$. The JCPDS file-numbers 38-1423 and 31-0967 were used to analyze UL, and 29-1077 for RLa and RLb. The lattice constants and cell volume of each leucite were determined from the 004 and 400 reflections for tetragonal form, and the 400 reflection for a cubic form. The density of the various leucites was measured to investigate the effect of the treatment of ion exchange by the Archimedes' principle using a pycnometer. The mean density of each leucite was determined from five measurements, and compared with the density calculated from the unit cell volume.

\section{Preparation of specimens}

Component No.3 (Weinstein et al.) glass powder was employed as a glass matrix for the composite porcelains containing each leucite. The component No.3 (CNT) was prepared according to the patent of Weinstein et al. ${ }^{2}$. CNT and the $30 \mathrm{vol} \%$ leucite powders were mixed thoroughly in the alumina mortar with isopropyl alcohol for 20 min. After mixing, approximately $0.6 \mathrm{~g}$ of each mixture consisting of glass and leucite was placed in a $20 \mathrm{~mm} \times 6 \mathrm{~mm}$ split metal mold and dry-compressed by hand with a plunger. The pressed compact was wetted by adding several drops of water, recompressed by a press, entirely removed from the mold, and dried at an elevated temperature. The specimens were then fired under a reduced pressure at a heating rate of $55^{\circ} \mathrm{C} / \mathrm{min}$, and held at the final firing temperature for $1 \mathrm{~min}$ in a furnace (ACE II, Shofu, Kyoto, Japan). The specimen groups and firing temperatures for leucite-containing and glass-only porcelains are summarized in Table 1.

\section{Flexural strength and fracture toughness}

After firing, the specimens were ground flat and parallel with 800 grit $\mathrm{SiC}$ abrasive paper to a final size of approximately $6.0 \mathrm{~mm} \times 1.5 \mathrm{~mm} \times 18.0 \mathrm{~mm}$. Both sides were polished with the liquid containing $1 \mu \mathrm{m}$ diamond powders. The flexural strength of all specimens was measured by a three-point bending test using a universal testing machine (AG-100, Shimazu, Kyoto, Japan), a $14 \mathrm{~mm}$ test span, and a crosshead speed of $0.5 \mathrm{~mm} / \mathrm{min}$. The flexural strength value was calculated from the maximum failure load, and the mean value and standard deviation were obtained from nine measurements.

After the flexural test, six fractured fragments of each group were randomly 
selected to measure the fracture toughness by an indentation method. The fractured specimens were mounted parallel to the bottom of a plastic mold $(12 \mathrm{~mm}$ in diameter and $3 \mathrm{~mm}$ deep) in a light-curing dental composite-resin. The porcelain surface of specimens then received a gold-coating (approximate thickness $40 \mathrm{~nm}$ ) to observe the indentation cracks clearly. The indentations were performed under immersion oil to diminish slow crack growth due to atmospheric moisture during measurement. A higher load of $98 \mathrm{~N}$ for the composite porcelains was used to obtain sufficiently long radial cracks that interacted with the leucite particles, using a Vickers microhardness tester (AVK-A2, Akashi, Yokohama, Japan). The glass-only specimens were measured using a second indentor (MVK-E, Akashi) at $9.8 \mathrm{~N}$. Within one minute after indentation, the developed crack lengths were measured by using a microscope attached to the hardness tester. Six to nine Vickers and five Knoop indentations were made on each specimen. The fracture toughness $\left(\mathrm{K}_{\mathrm{IC}}\right)$ was calculated from an equilibrium equation of load-to- $\operatorname{crack}^{13)} ; \mathrm{K}_{\mathrm{IC}}=0.016(\mathrm{E} / \mathrm{H})^{1 / 2}\left(\mathrm{P} / \mathrm{c}^{3 / 2}\right)$, where $\mathrm{c}$ is the half length of the median crack, $\mathrm{P}$ is applied load, $\mathrm{E} / \mathrm{H}$ is elastic-modulus-to-hardness ratio. The Knoop indentation measurement was performed to determine the $\mathrm{E} / \mathrm{H}$ ratio of each specimen $^{14}$. The mean fracture toughness value was determined from at least 36 indentations.

Mean values of flexural strength and fracture toughness of each group were tested to determine a significant difference by one-factor ANOVA and Fisher's PLSD post-hoc multiple-comparison procedure. The microstructure of each specimen was observed using a scanning electron microscope (S-700, Hitachi, Tokyo, Japan), specifically to investigate the crack tip interactions with leucite particles.

\section{RESULTS}

\section{Rubidium-ion-exchanged leucite}

The x-ray diffraction (XRD) patterns at $50^{\circ} \mathrm{C}$ for two $\mathrm{Rb}$-ion-exchanged leucites (RLa and RLb) and the unmodified leucite (UL) are shown in Fig. 1. The peak data of $\mathrm{XRD}$ for UL closely corresponded to that of synthetic leucite prepared stoichiometrically (JCPDS file No.38-1423). RLa and RLb were identified as rubidium-aluminum-silicate $\left(\mathrm{RbAlSi}_{2} \mathrm{O}_{6}\right)$ by the XRD analysis with JCPDS file-number 29-1077. The patterns of high-temperature XRD for RLa and RLb are displayed in Fig. 2. The temperature ranges of RLa and RLb for transforming from tetragonal to cubic phases were approximately $(400$ to 450$){ }^{\circ} \mathrm{C}$ and (400 to 550$){ }^{\circ} \mathrm{C}$, respectively. The transforming temperature of leucite was largely dropped by the ion-exchange with rubidium, as compared to that of $\mathrm{UL}^{6)}(550$ to 650$){ }^{\circ} \mathrm{C}$. Fig. 3 shows the temperature dependence of the lattice constants of the various leucites. The lattice parameters and the unit cell volume $(\mathrm{V})$ of UL were $\mathbf{a}=13.105 \dot{\mathrm{A}}, \mathbf{c}=13.776 \dot{\mathrm{A}}$ and $\mathrm{V}=2366.1 \dot{\mathrm{A}}^{3}$ at 50 ${ }^{\circ} \mathrm{C}$. The lattice parameters and volume $\mathrm{V}$ of $\mathrm{RLa}$ and $\mathrm{RLb}$ showed similar values to those of Rb-leucite synthesized ${ }^{15,16)}$ at room temperature, i.e. larger than those of UL.

The mean values of the measured density $\left(D_{m}\right)$ and the calculated density $\left(D_{c}\right)$ of each leucite appear in Table 2. A good agreement between the $D_{m}$ and the $D_{c}$ value 


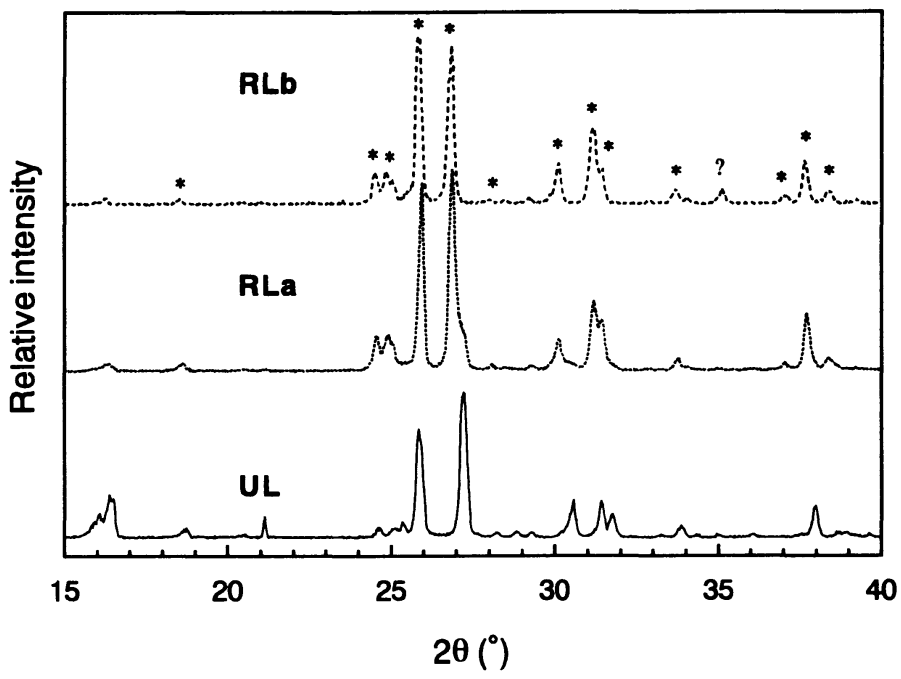

Fig. 1 X-ray diffraction patterns of leucite ion-exchanged with rubidium nitrate at $450^{\circ} \mathrm{C}(\mathrm{RLa})$ or $650^{\circ} \mathrm{C}(\mathrm{RLb})$, and the unmodified-leucite (UL) at $50^{\circ} \mathrm{C} .{ }^{*}$; Rubidium Aluminium Silicate (JCPDS file No.29-1077).

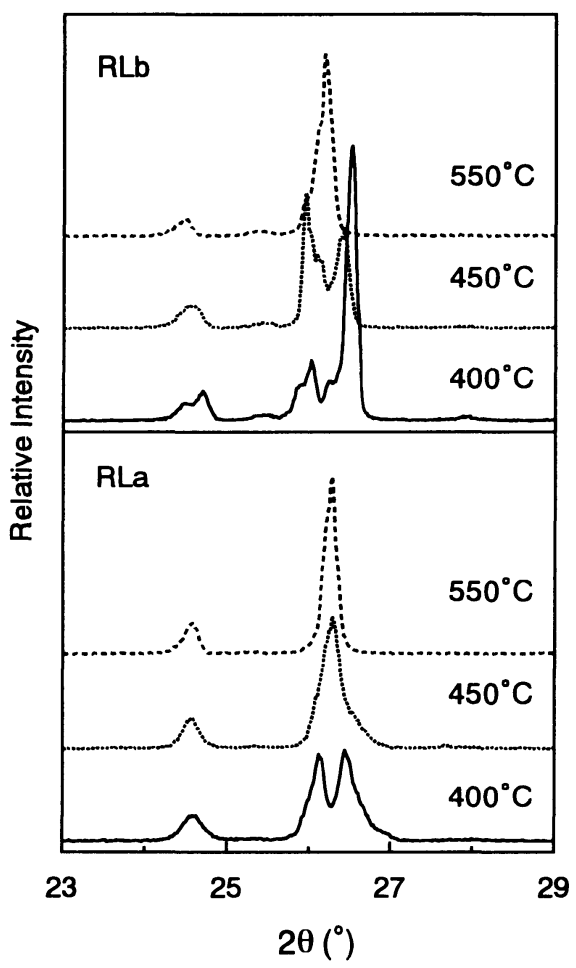

Fig. 2 X-ray diffraction patterns of RLa and RLb, showing the polymorphic transformation from tetragonal to cubic phase. 


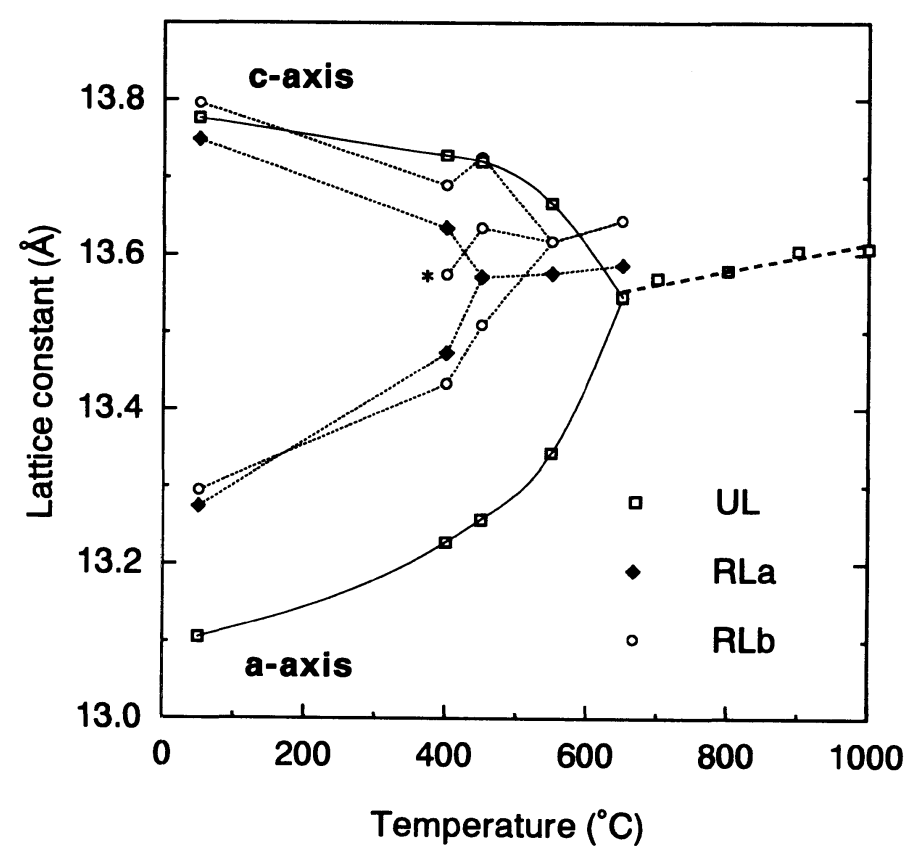

Fig. 3 Temperature dependence of lattice constants. The dotted line of UL was extrapolated from the percentage volume expansion data of a natural leucite ${ }^{15}$. Asterisk indicates that the tetragonal and cubic phases of RLb coexist.

Table 2 Measured density $\left(D_{m}\right)$, calculated density $\left(D_{c}\right)$, and unit cell volume $(\mathrm{V})$ of various leucites

\begin{tabular}{cccc}
\hline Leucite & $\mathrm{D}_{\mathrm{m}}\left(\mathrm{g} / \mathrm{cm}^{3}\right)$ & $\mathrm{D}_{\mathrm{c}}\left(\mathrm{g} / \mathrm{cm}^{3}\right)$ & $\mathrm{V}\left(\dot{\AA}^{3}\right)$ \\
\hline $\mathrm{UL}$ & $2.456 \pm 0.005$ & 2.452 & 2366.1 \\
$\mathrm{RLa}$ & $2.622 \pm 0.006$ & 2.903 & 2422.6 \\
$\mathrm{RLb}$ & $2.685 \pm 0.005$ & 2.884 & 2438.8 \\
\hline
\end{tabular}

was shown in UL, similar to the reference value for synthetic leucite $\left(D_{x}=2.469\right.$, JCPDS 38-1423). RLa and RLb showed a significant increase in density $(p<.01)$ with rubidium ion-exchange. However, the $D_{m}$ values of RLa and RLb were lower than their values $D_{c}$ values, though the $D_{c}$ values are about the same as the value $\left(D_{x}\right.$ $=2.893$, JCPDS 29-1077) of synthetic Rb-leucite.

\section{Mechanical properties}

The mechanical properties of the glass-only and glass-leucite porcelains are shown in Table 3. The mean flexural strength of glass-only porcelain, CNT, was $66 \mathrm{MPa}$. In 
Table 3 Flexural strength (FS), elastic-modulus-to-hardness ratio $(\mathrm{E} / \mathrm{H})$, and fracture toughness $\left(\mathrm{K}_{\mathrm{IC}}\right)$ of specimens

\begin{tabular}{cccc}
\hline Specimen & $\mathrm{FS}(\mathrm{MPa})$ & $\mathrm{E} / \mathrm{H}$ & $\mathrm{K}_{\mathrm{IC}}\left(\mathrm{MPa} \cdot \mathrm{m}^{1 / 2}\right)$ \\
\hline $\mathrm{CNT}$ & $66.3 \pm 7.2$ & $14.6 \pm 1.4$ & $0.80 \pm 0.12$ \\
$\mathrm{UL}-\mathrm{C}$ & $66.9 \pm 6.9$ & $10.5 \pm 0.5$ & $1.18 \pm 0.19$ \\
$\mathrm{RLa}-\mathrm{C}$ & $75.1 \pm 4.9$ & $10.7 \pm 0.6$ & $1.48 \pm 0.27$ \\
RLb-C & $65.6 \pm 5.6$ & $10.9 \pm 0.7$ & $1.18 \pm 0.21$ \\
\hline Vertical bars mean no significant & difference at $\mathrm{p}<0.05(\mathrm{FS})$ and \\
$\mathrm{p}<0.01\left(\mathrm{~K}_{\mathrm{IC}}\right)$ level.
\end{tabular}

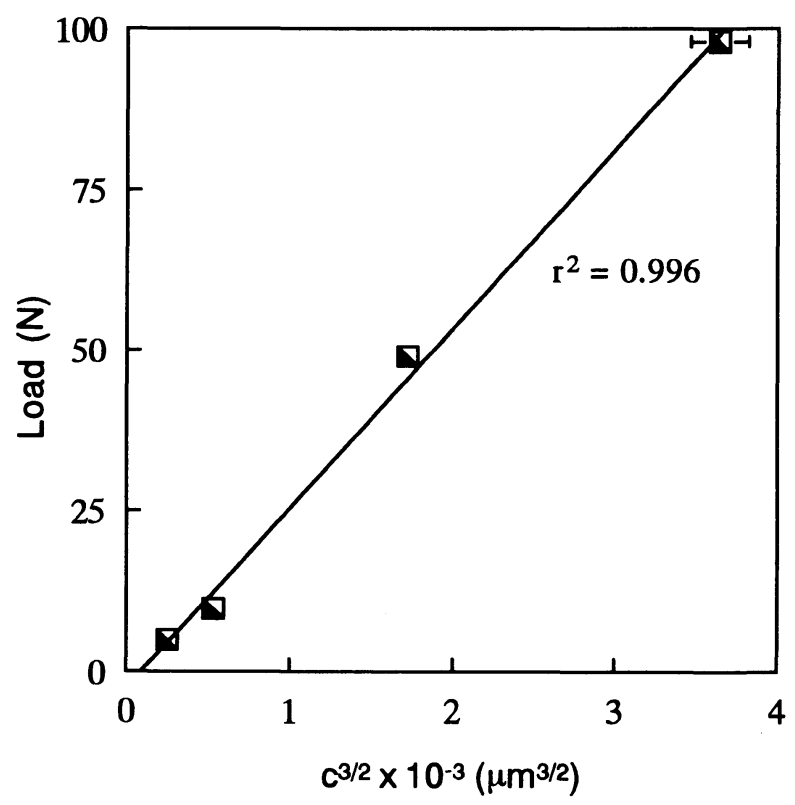

Fig. 4 Relationship between load (P) and median crack length $\left(c^{3 / 2}\right)$ of the composite porcelain containing RLa.

the values of flexural strength for composite porcelains, there was no difference between RLb-C and UL-C, and the values were almost the same as that of CNT. However, the composite porcelain of $\mathrm{RLa}-\mathrm{C}$ showed significantly increased mean flexural strength, compared with RLb-C and UL-C $(p<0.05)$. The mean fracture toughness $\left(\mathrm{K}_{\mathrm{IC}}\right)$ value of $\mathrm{RLa}-\mathrm{C}$ also showed a significantly higher value, in comparison to those of CNT, UL-C, and $\mathrm{RLb}-\mathrm{C}(\mathrm{p}<0.01)$. The $\mathrm{E} / \mathrm{H}$ ratios of glass-leucite specimens were similar to one another, except for that of the glass-only specimens. Therefore, the $\mathrm{K}_{\mathrm{IC}}$ values of various glass-leucite porcelains were practically determined by the dimensions of cracks that emanated from the Vickers indentation. To verify the validity of the $\mathrm{K}_{\mathrm{IC}}$ magnitude, the relationships ${ }^{17)}$ between indentation-load $(\mathrm{N})$ and crack length $\left(\mathrm{C}^{3 / 2}\right)$ of RLa-C was obtained from each of six indentations at $4.9,9.8,49,98$ $\mathrm{N}$, as shown in Fig. 4. It is assumed that the $\mathrm{K}_{\mathrm{IC}}$ magnitude of $\mathrm{RLa}-\mathrm{C}$ is valid from 
the linearity of their relationship.

\section{DISCUSSION}

An investigation of synthetic $\mathrm{Rb}\left[\mathrm{AlSi}_{2} \mathrm{O}_{6}\right]$ revealed that it can exist in two easily reversible polymorphic forms without changes in phase composition ${ }^{16)}$. The hightemperature XRD analysis showed that the $\mathrm{K}$-leucite (UL), $\mathrm{K}\left[\mathrm{AlSi}_{2} \mathrm{O}_{6}\right]$, was changed into $\mathrm{Rb}$-leucite, $\mathrm{Rb}\left[\mathrm{AlSi}_{2} \mathrm{O}_{6}\right]$, by the rubidium ion-exchange treatment. The $\mathrm{RLa}$, in particular, showed a similar pattern with a synthetic Rb-leucite in the transforming behavior $^{15)}$. Thus, the rubidium ion-exchanges increased the density value of leucite (Table 2). However, the $D_{m}$ values of $R L a$ and $R L b$ were lower than their $D_{c}$ values. This indicates that the Rb-exchanged particles seemed not to be entirely transformed into $\mathrm{Rb}$-leucite. Presumably, the rubidium-exchange substitutes partly $\mathrm{K}$ and some minor elements of leucite for $\mathrm{Rb}$, and/or the vacancies in leucite are filled with rubidium ions. Rubidium has a larger ionic radius than potassium and sodium. As a result, the rubidium-exchanged leucite crystals would form considerably denser particles than K-leucite. However, the RLb revealed an unstable thermal behavior, as shown in Fig. 3. This was probably caused by the higher ion-exchange temperature $\left(650^{\circ} \mathrm{C}\right)$, i.e. $\mathrm{RLb}$ was obtained by the rubidium-exchange at a temperature after the displacive transformation of leucite. The effects of rubidium-exchange time and temperature kinetics on the toughening of leucite particles must therefore be considered.

The results of ANOVA and Fisher's PLSD analysis showed that the composite porcelain (RLa-C) containing RLa had significantly higher values in flexural strength $(\mathrm{p}<.05)$ and $\mathrm{K}_{\mathrm{IC}}(\mathrm{p}<.01)$ than the composite porcelain containing UL or RLb. These results suggest that the RLa particle would be more effective in strengthening and toughening than UL and RLb. On the other hand, the linear thermal expansion coefficient (TEC) of tetragonal leucite at each temperature can be estimated from each lattice parameter; $\alpha=\left(\alpha_{\mathrm{c}}+2 \alpha_{\mathrm{a}}\right) / 3$, where $\alpha_{\mathrm{c}}$ and $\alpha_{\mathrm{a}}$ are the TEC values of each cell edge, $\mathrm{c}$ and a. The calculated TEC values from Fig. 3 for tetragonal forms of UL, $\mathrm{RLa}$, and $\mathrm{RLb}$ were 19,21 , and $13 \times 10^{-6} /{ }^{\circ} \mathrm{C}$ at the temperature ranges of 50 to 550 ${ }^{\circ} \mathrm{C}$, 50 to $400{ }^{\circ} \mathrm{C}$, and 50 to $400{ }^{\circ} \mathrm{C}$, respectively. However, a cubic form of leucite shows a low and constant TEC value, because of its uncollapsed nature ${ }^{15)}$. Thus, the $\mathrm{Rb}$-leucites will also have a low TEC value at temperatures above the transforming point $\left(>400^{\circ} \mathrm{C}\right)$. This property of the Rb-leucites will decrease the temperature interval at which TEC mismatch between leucite-particles and glass-matrix arises during cooling. Moreover, the change in dimensions of the cell parameters with temperature is smaller in RLa than that of UL (see Fig. 3). Therefore, the residual stress in the glass-matrix that occurred with the TEC mismatch would be reduced in RLa-C. These results indicate that the relatively higher strength and toughness of RLa-C were not caused by residual stress.

Fig. 5 shows the patterns of crack propagation generated by Vickers indentation (98 N) on the polished surfaces of UL-C and RLa-C. There was no significant difference in the microscopic features of the leucite particles in the composite porcelains, 

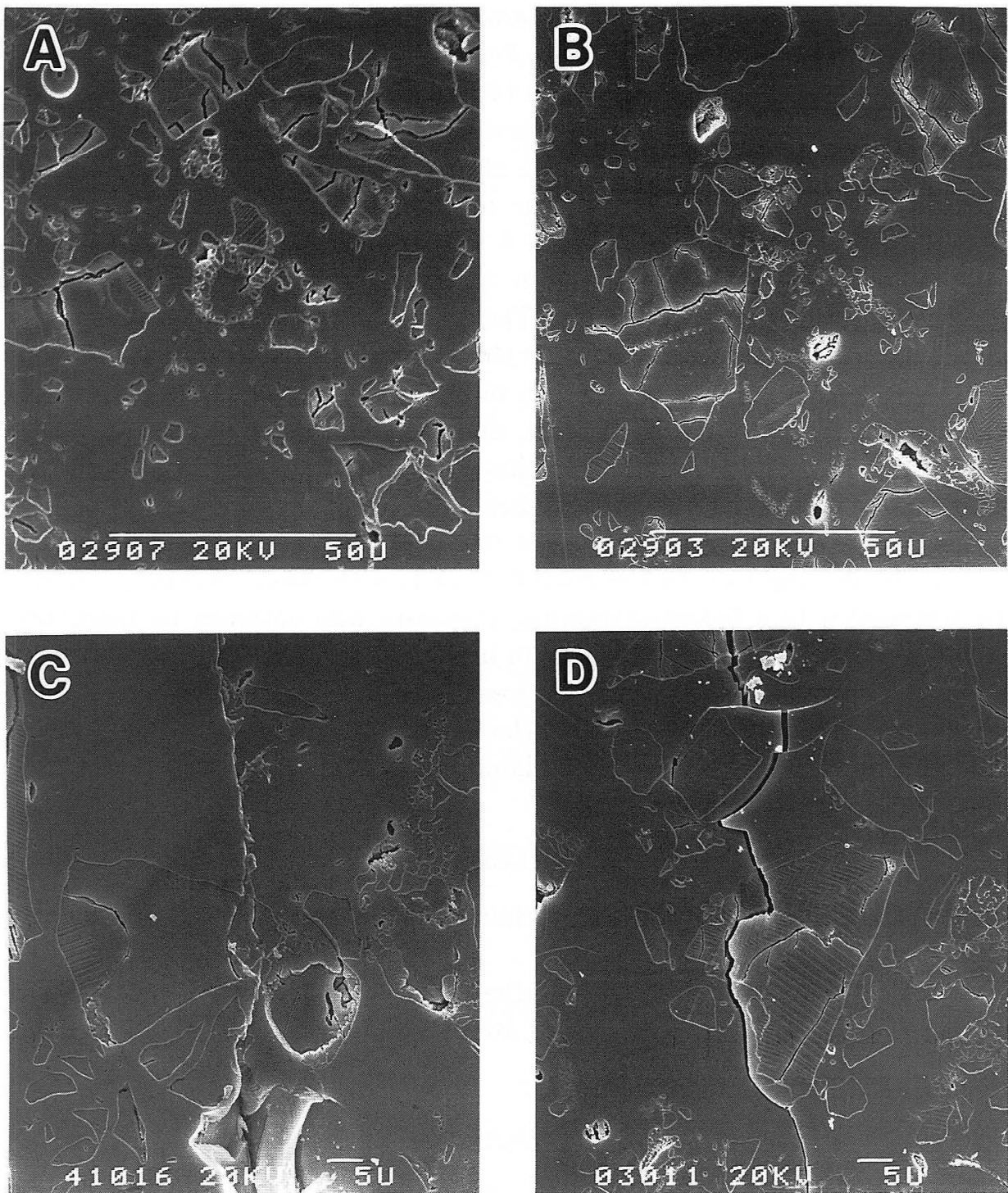

Fig. 5 Scanning electron micrographs of unmodified leucite-containing porcelain $\mathrm{UL}-\mathrm{C}$ (A) and Rb-exchanged leucite-containing porcelain RLa-C (B), and their crack patterns after indentation (98 N) in UL-C (C) and RLa-C (D). The specimens were etched with $1 \% \mathrm{HF}$ for $15 \mathrm{~s}$.

which shows a twined lamellar structure ${ }^{18)}$. However, the crack propagation in the RLa-C was deflected by direct crack-tip interaction with leucite particles, compared with those in UL-C. The crack-deflections hinder crack propagation and reduce the crack driving force, resulting in a reducing of crack extension ${ }^{19)}$. Therefore, the strengthening or toughening in RLa-C would be attributed to the crack-deflection action of RLa particles. This is probably caused by an increase of inherent crack 
resistance in RLa particles which is achieved by the rubidium-exchange treatment.

Recently, there have been several studies about the effects of adding alkali oxide to dental porcelain powder. The addition of cesium oxide to a leucite porcelain easily stabilizes the cubic leucite at room temperature ${ }^{20)}$. The cubic leucite (pollucite) stabilization, however, results in a decrease in strength ${ }^{21)}$, although there is a possibility that transformation toughening can occur in the cubic leucite ${ }^{22)}$. Denry et al ${ }^{23)}$ reported that rubidium-exchange $\left(450^{\circ} \mathrm{C}\right.$ for $\left.4 \mathrm{~h}\right)$ of a leucite-reinforcing porcelain powder resulted in a significant increase in strength and a decrease in the thermal contraction coefficient of the porcelain. They also found that $\mathrm{Rb}$-leucite was the only crystalline phase in the fired porcelain by the XRD analysis. Rb-leucite is also easily obtained by a synthetic low-temperature modification or hydrothermal reactions ${ }^{24}$. $\mathrm{Rb}$-leucite and K-leucite are isostructural, and their refractive indices show a similar value $^{24)}$. This suggests that the Rb-leucite can be used as substitute for K-leucite without loss of translucency in dental porcelain.

In this study, we tried to improve the mechanical properties of leucite-containing porcelain by increasing the crack-resistibility of leucite filler. Statistical strengthening and toughening in a leucite-containing porcelain was obtained by using the crystalline leucite ion-exchanged with rubidium at $450^{\circ} \mathrm{C}$. However, the measured value of density of the $\mathrm{Rb}$-exchanged leucite disagreed with the theoretically calculated value. A more effective process for toughening the leucite crystals will be needed for further strengthening of leucite-containing porcelain.

\section{ACKNOWLEDGMENTS}

The authors wish to thank Shimadzu Techno-Research Inc. for the high-temperature XRD measurements.

Part of this study was presented at the 75th General Session and Exhibition of the International Association for Dental Research, March 19-23, 1997, Orlando, FL, USA.

\section{REFERENCES}

1) Kappert, H.F.: Dental materials: New ceramic systems, In: Proceedings of conference on clinically appropriate alternatives to amalgam: Biophysical factors in restorative decision-making, Oct. 30 - Nov. 2, Munich, Germany, 1996, pp.180-199.

2) Weinstein, M., Katz, S. and Weinstein, A. B.: Fused porcelain-to-metal teeth, U.S. Patent No.3,052,982, Sept. 11, 1962.

3) Burk, B. and Burnett, A. P.: Leucite-containing porcelains and method of making same, U.S. Patent No.4,101,330, Jul. 18, 1978.

4) Smyth, M. and Schulman, A.: The effect of leucite crystals on the physical properties of dental porcelain, $J$ Dent Res 60 (Spec Iss) : 406, Abstr No.383, 1981.

5) Kelly, J.R., Nishimura, I. and Campbell, S. D.: Ceramics in dentistry: Historical roots and current perspectives, $J$ Prosthet Dent 75(1): 18-32, 1996.

6) Lee, H.-H., Kon, M. and Asaoka, K.: Influence of modification of $\mathrm{Na}_{2} \mathrm{O}$ in a glass matrix on the strength of leucite-containing porcelains, Dent Mater $J$ 16(2): 134-143, 1997.

7) Ohnuki, Y., Saito, Y. and Miyazaki, T.: Mechanical properties of low-fusing porcelains 
for multi-purpose gold alloys, In: New Dental Science, Quintessence Dent Technol 22(8) : 21-31, 1997. (in Japanese)

8) Ueda, H., Shinya, A., Tohyama, Y. and Yokozuka, S.: Fracture toughness of porcelain using indentation method, Shigaku 78(3): 487-504, 1990. (in Japanese)

9) Morena, R., Lockwood, P.E. and Fairhurst, C. W.: Fracture toughness of commercial dental porcelains, Dent Mater 2 : 58-62, 1986.

10) Denry, I. L., Crimaldi, A. J. and Rosenstiel, S. F.: Fracture toughness, Vickers hardness and elastic modulus of crystalline leucite, $J$ Dent Res 74, Abstr No.38, 1995.

11) Henderson, M. B.: Minor element chemistry of leucite and psedoleucite, Mineral Mag 35 : 596-603, 1965.

12) Martin, R.F. and Lagache, M.: Cell edges and infrared spectra of synthetic leucites and pollucites in the system $\mathrm{KAlSi}_{2} \mathrm{O}_{6}-\mathrm{RbAlSi}_{2} \mathrm{O}_{6}-\mathrm{CsAlSi}_{2} \mathrm{O}_{6}$, Can Mineral 13:275-281, 1975.

13) Anstis, G. R., Chantikul, P., Lawn, B. R. and Marshall, D. B.: A critical evaluation of indentation technique for measuring fracture toughness: I. direct crack measurements, $J$ Am Ceram Soc 64(9) : 533-538, 1981.

14) Marshall, D. B., Noma, T. and Evans, A. G.: A simple method for determining elasticmodulus-to-hardness ratios using Knoop indentation measurements, $J$ Am Ceram Soc 65 : C175-C176, 1982.

15) Taylor, D. and Henderson, C. M. B.: The thermal expansion of the leucite group of minerals, Am Mineral 53 : 1476-1489, 1968.

16) Kosorukov, A.A. and Nadal, L. G.: High-temperature $\mathrm{x}$-ray diffraction of synthetic leucite, $\mathrm{Rb}\left[\mathrm{AlSi}_{2} \mathrm{O}_{6}\right]$, and pollucite, Sov Phys Crystallogr 31(2): 148-151, 1986.

17) The ceramic society of Japan: Advanced ceramics, Ohmu Co., Tokyo, 1993, pp.65-69. (in Japanese)

18) Palmer, D. C., Putnis, A. and Salje, E. K. H.: Twinning in tetragonal leucite, Phys Chem Minerals $16: 298-303,1988$.

19) Ruf, H. and Evans, A. G.: Toughening by monoclinic zirconia, J Am Ceram Soc 66(5): 328-332, 1983.

20) Prasad, A., and Vaidyanathan, T. K.: Crystallization of cubic leucite by composition additives, $J$ Dent Res 69 (Spec Iss) : 211, Abstr No.814, 1990.

21) Denry, I. L., Mackert, J. R. Jr., Holloway, J.A. and Rosenstiel, S. F.: Effect of cubic leucite stabilization on the flexural strength of feldspathic dental porcelain, $J$ Dent Res $\mathbf{7 5}$ (12) : 1928-1935, 1996.

22) Rasmussen, S. T. and O'Brien, W. J.: Cesium stabilized high leucite porcelain, $J$ Dent Res 74 (Spec Iss) : 165,. Abstr No.1232, 1995.

23) Denry, I. L., Holloway, J. A. and Rosenstiel, S. F.: Effect of rubidium-leucite on the flexural strength and thermal expansion of leucite-reinforced porcelain, J Dent Res 75 (Spec Iss) : 125, Abstr No.863, 1996.

24) Barrer, R. M., Baynhan, J.W. and McCallum, N.: Hydrothermal chemistry of silicates. Part V. Compounds structurally related to analcite, J Chem Soc 822 : 4035-4041, 1953. 